\title{
Mediastinal hydatid cyst rupturing into the pleural cavity associated with pneumothorax: Case report and review of the literature
}

\author{
Mohd Shameem MD ${ }^{1}$, Rakesh Bhargava $M D^{1}$, Zuber Ahmad MD¹, Nazish Fatima MD², Naveed Nazir Shah MD
}

\begin{abstract}
M Shameem, R Bhargava, Z Ahmad, N Fatima, NN Shah. Mediastinal hydatid cyst rupturing into the pleural cavity associated with pneumothorax: Case report and review of the literature. Can Respir J 2006;13(4):211-213.

Hydatid disease remains a serious health problem in Mediterranean countries. Living in a rural area is an important risk factor for the disease. Hydatid cysts are usually located in the liver, lungs and brain. Mediastinal hydatid disease is very rare and has been noted only anecdotally in the literature. The present article reports a case of a mediastinal hydatid cyst rupturing into the pleural cavity, which was associated with pneumothorax of the same side. The patient's previous chest $\mathrm{x}$-rays (posteroanterior and left lateral views) showed a well-defined mediastinal mass on the left side, and contrast-enhanced computed tomography of the thorax (taken a few days after the chest x-ray) showed multiple round-to-oval soft tissue opacities with partial collapse of the left lung. An indirect hemagglutination test for echinococcus was positive. Even after two weeks of intercostal tube drainage, the patient's condition did not improve. During thoracotomy, multiple daughter cysts were found in the pleural cavity, and the diagnosis of a hydatid cyst was confirmed after histopathological examination.
\end{abstract}

Key Words: Hydatid; Mediastinum; Pneumothorax

\section{Un kyste hydatique médiastinal se rompant dans la cavité pleurale et associé à un pneumothorax : Rapport de cas et analyse bibliographique}

\begin{abstract}
La maladie hydatique demeure un problème de santé préoccupant dans les pays méditerranéens. Vivre dans une région rurale est un facteur de risque important de la maladie. Les kystes hydatiques se trouvent généralement dans le foie, les poumons et le cerveau. La maladie hydatique médiastinale est très rare et n'a été déclarée que de manière empirique dans les publications. Le présent article fait état d'un kyste hydatique médiastinal qui s'est rompu dans la cavité pleurale, en association avec un pneumothorax du même côté. Les radiographies thoraciques précédentes du patient (vue postéroantérieure et latérale gauche) avaient révélé une masse médiastinale bien définie du côté gauche, et une tomodensitométrie du thorax avec injection d'un agent de contraste (prise quelques jours après la radiographie thoracique) ont permis de distinguer de nombreuses opacités ovales ou rondes des tissus mous et un collapsus partiel du poumon gauche. Une épreuve d'inhibition de l'hémagglutination indirecte était positive à l'échinococcose. Même après un drainage par sonde intercostale de deux semaines, l'état du patient ne s'était pas amélioré. Pendant la thoracotomie, de multiples kystes fils ont été découverts dans la cavité pleurale, et le diagnostic de kyste hydatique a été confirmé après un examen histopathologique.
\end{abstract}

$\mathrm{H}$ ydatid disease is primarily an illness of residents in rural areas who frequently come into contact with carnivores, sheep and cows. Human hydatid disease, caused by the larval form of Echinococcus granulosus, has a worldwide distribution, and is endemic in many countries in the Mediterranean region, the Middle and Far East, and South America (1). Hydatid cysts have a predilection to locate in the liver, lungs and brain. Although many uncommon locations have been reported, the disease is rarely present in the mediastinum. Approximately 100 cases have been described in the English literature so far (2-5). Although the features of these mediastinal diseases have been described in small series and case reports, no large series defining the features of mediastinal cysts has been published. In the present case report, we describe a case of a mediastinal hydatid cyst that ruptured into the pleural cavity and was associated with pneumothorax of the same side.

\section{CASE PRESENTATON}

A 45-year-old woman presented to the emergency room with complaints of acute onset chest pain on the left side of the chest and breathlessness of sudden onset. She had been complaining of dull, aching chest pain, cough with expectoration and low-grade fever for the previous three months.
On general examination, the patient was hemodynamically unstable, with a pulse rate of 100 beats/min and a systolic blood pressure of $70 \mathrm{mmHg}$. The patient was febrile and cyanotic. The use of accessory muscles of respiration was observed. On percussion, a hyper-resonant note was heard in the left side of the chest, with a normal percussion note in the right side. On auscultation, breath sounds were absent in the left side of the chest, whereas on the right side, normal vesicular breath sounds were heard without added sounds. Results from routine laboratory testing are shown in Table 1 .

Serum electrolyte levels and liver function test results were normal. Ultrasonography of the abdomen was normal. A chest $\mathrm{x}$-ray (posteroanterior view) showed pneumothorax with multiple rounded opacities (Figure 1); her previous chest $\mathrm{x}$-ray showed a sharply circumscribed, homogenous mass visible in the left mid-zone, having a smooth but lobulated contour (Figure 2). Moreover, a chest x-ray (left lateral view) showed an opacity in the mediastinum, with compression atelectasis of the surrounding lung (Figure 3). Contrast-enhanced computed tomography of the thorax showed multiple, rounded, well-defined cystic masses, with partial collapse of the lung (Figure 4). An indirect hemagglutination test for echinococcus was positive.

${ }^{1}$ Department of Tuberculosis and Chest Diseases; ${ }^{2}$ Department of Microbiology, Jawaharlal Nehru Medical College, Aligarh Muslim University, Aligarh, India

Correspondence: Dr Mohd Shameem, Department of Tuberculosis and Chest Diseases, Jawaharlal Nehru Medical College, Aligarh Muslim University, Aligarh (Uttar Pradesh) 202002 India. Telephone 91-941-273-1835, fax 91-571-270-2758, e-mail doctor_shameem123@rediffmail.com 


\section{TABLE 1}

\section{Laboratory findings}

\begin{tabular}{lc}
\hline Hemoglobin $(\mathrm{g} / \mathrm{L})$ & 112 \\
Total leukocyte count $\left(\times 10^{9} / \mathrm{L}\right)$ & 12.5 \\
Differential leukocyte count $(\%)$ & 60 \\
$\quad$ Neutrophils & 12 \\
Lymphocytes & 8 \\
Monocytes & 20 \\
Eosinophils & 1.0 \\
Absolute eosinophil count $\left(\times 10^{9} / \mathrm{L}\right)$ & 90 \\
Erythrocyte sedimentation rate $(\mathrm{mm} / \mathrm{h})$ & \\
Arterial blood gases & $40 \mathrm{mmHg}$ \\
Arterial $\mathrm{O}_{2}$ tension $\left(P \mathrm{O}_{2}\right)$ & $64 \mathrm{mmHg}(\mathrm{pH} 7.39)$ at an $\mathrm{FiO}_{2}$ of 0.21 \\
Arterial $\mathrm{CO}_{2}$ tension $\left(P \mathrm{CO}_{2}\right)$ &
\end{tabular}

$\mathrm{FiO}_{2}$ Fraction of inspired $\mathrm{O}_{2} ; \mathrm{PCO}_{2}$ Partial pressure of $\mathrm{CO}_{2} ; \mathrm{PO}_{2}$ Partial pressure of $\mathrm{O}_{2}$

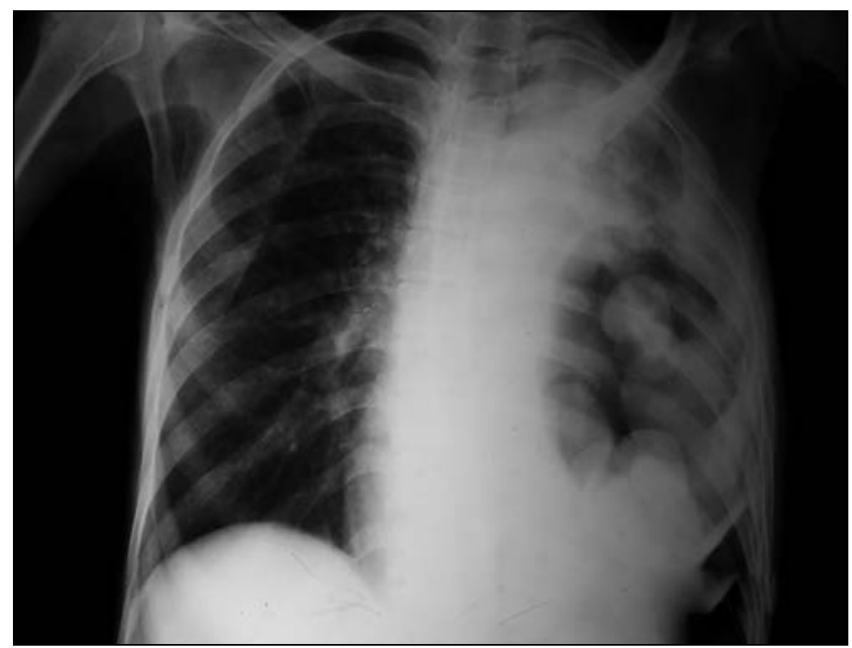

Figure 1) Chest $x$-ray (posteroanterior view) showing left-sided pneumothorax with multiple rounded opacities suggestive of daughter hydatid cysts

Initial resuscitation of the patient from shock was followed by closed pleural drainage. Thoracotomy was performed after two weeks. At the time of thoracotomy, hydatid membranes with multiple daughter hydatid cysts of varying sizes were found lying in the pleural cavity. There was an opening in the left lower lobe with a bronchial communication. The membranes and daughter cysts were removed, and mediastinal pleura, along with the pericystic wall, was excised. Decortication was performed and the fistula was closed.

Histopathological components were the stroma, areas of liquified and nonliquified necrosis, metacestodal vesicles, entrapped host tissue, microcalcification and protoscolex in a brood capsule.

Postoperative recovery was uncomplicated and the patient was discharged on albendazole therapy.

\section{DISCUSSION}

Adult E granulosus is a worm that resides in the jejunum of dogs and other canines, and produces eggs that are passed in the stool. The eggs, ingested by intermediate hosts (cows, sheep and humans), liberate an embryo in the duodenum, which passes through the intestinal mucosa to enter portal circulation. Most of these embryos get trapped in the liver; the rest pass through the liver and scatter to other organs and

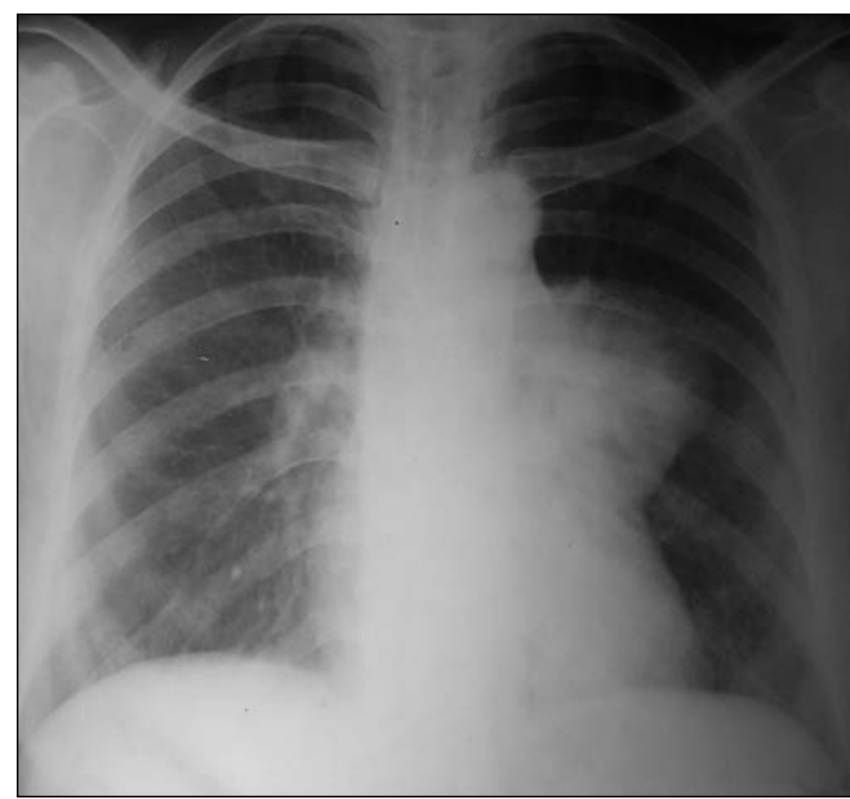

Figure 2) Chest $x$-ray (posteroanterior view, taken two months before) showing a well-circumscribed lobulated opacity in the left mid-zone

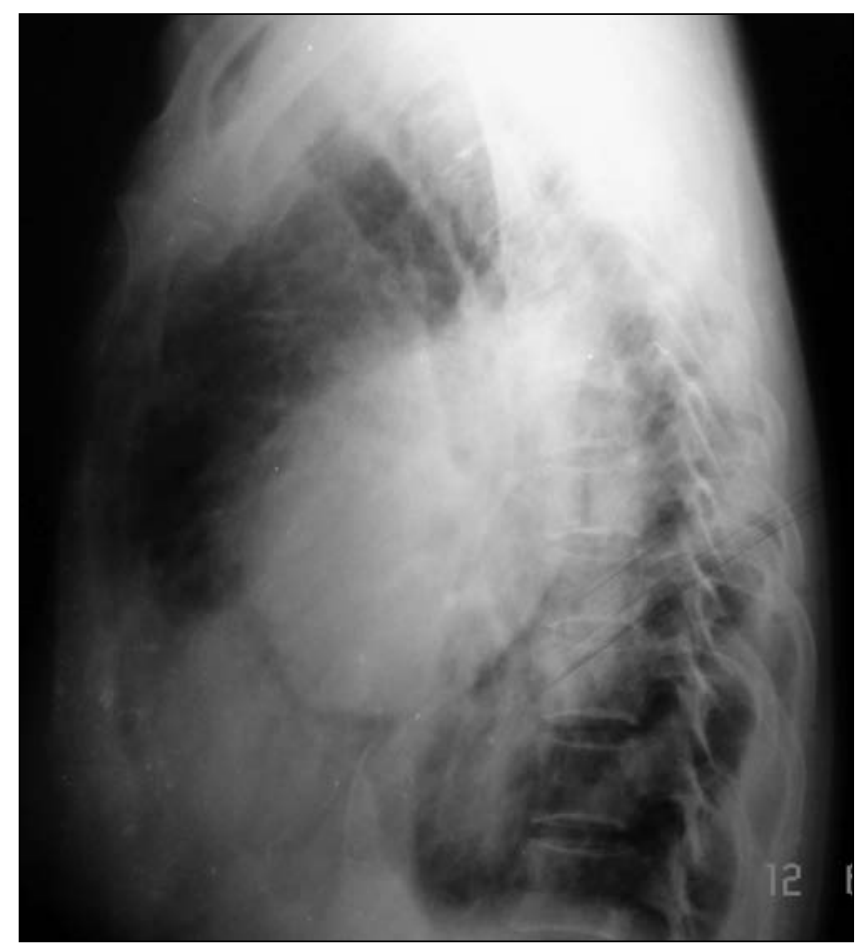

Figure 3) Chest $x$-ray (left lateral view) showing an opacity in the middle mediastinum with compressive atelectasis of the surrounding lung

develop into hydatid cysts. Consequently, hydatid cysts may be found in every tissue and organ.

Echinococcal cysts are composed of tissue from both the host and parasite. A nonruptured cyst is surrounded by the pericyst - a layer derived from compressed host tissue and chronic inflammatory cells (6). The true cyst wall is derived from the parasite and is arranged in two layers. The acellular outer laminated ectocyst is $1 \mathrm{~mm}$ to $2 \mathrm{~mm}$ thick and is lined by a one-cell thick germinal membrane, the endocyst. The endocyst produces hydatid fluid and scoleces, which are infectious, miniature, 
adult tapeworms. Intracystic fluid pressures of up to $58.8 \mathrm{mmHg}$ (7) keep the parasitic membranes tightly applied to the pericyst. The endocyst is fragile $(8,9)$ and is normally protected from rupture by the tougher pericyst.

Hydatid cysts are rarely present in the mediastinum. From collective statistics of all studies, the occurrence of mediastinal hydatid disease varies from $0 \%$ to $6 \%$ (10). Rakower and Milwidsky (10) examined more than 23,000 patients with hydatid disease; only $25(0.1 \%)$ hydatid cysts were reported in the mediastinal compartment and paravertebral sulcus. Thameur et al (4) identified mediastinal hydatid cysts in eight of $1619(0.5 \%)$ intrathoracic hydatid cysts.

Eroglu et al (11) reported $11(2.6 \%)$ cases of primary mediastinal hydatid cysts in their 427 patients with thoracic hydatid disease in Turkey (endemic region for hydatid disease).

Symptoms and complications of mediastinal cysts depend on the size, location and involvement of neighbouring structures $(12,13)$, and range from being asymptomatic to having retrosternal pain, cough, dysphagia, dyspnea, or severe compression of the trachea and superior vena cava $(2,5)$. Marti-Bonmati et al (12) reported a case in which the cyst ruptured into the aorta. Eroglu et al (11) reported a case of a mediastinal hydatid cyst rupturing into the pleural cavity.

Hydatid cysts in the lung can cause complications. The cyst may erode into the bronchus, with air entering the various layers of the parasite to produce any one of several $x$-ray appearances (14), or the cyst may rupture, with the patient coughing out the hydatid fluid and membranes. The incidence of pneumothorax in patients with hydatid lung disease is reported to vary from $0.5 \%$ to $3.2 \%(15,16)$. When a subpleural hydatid cyst increases in size, it incorporates the visceral pleura to form a pleuro-pericyst layer. An inflammatory reaction between the two pleural surfaces may prevent rupture of the hydatid cysts into the pleural space. However, if the cyst increases in size before adhesions have formed, rupture into the pleural cavity can occur (17). The hydropneumothorax that follows may be of the tension type (18). Once the cyst has ruptured, diagnostic measures such as the Casoni test, the Weinberg complement fixation test and the total eosinophil

\section{REFERENCES}

1. Petersen C, Mills J. Parasitic infections. In: Murray JF, Nadel JA, eds. Textbook of Respiratory Medicine. Philadelphia: WB Saunders Co, 1994:1201-43.

2. Heras F, Ramos G, Duque JL, Garcia Yuste M, Cerezal LJ, Matilla JM. [Mediastinal hydatid cysts: 8 cases]. Arch Bronconeumol 2000;36:221-4.

3. Karnak I, Ciftci AO, Tanyel FC. Hydatid cyst: An unusual etiology for a cystic lesion of the posterior mediastinum. J Pediatr Surg 1998;33:759-60.

4. Thameur H, Chenik S, Abdelmoulah S, et al. [Thoracic hydatidosis. A review of 1619 cases]. Rev Pneumol Clin 2000;56:7-15.

5. Shields TW. Mesothelial and other less common cysts of the mediastinum. In: Shields TW, ed. General Thoracic Surgery, 5th edn. Philadelphia: Lippincott Williams \& Wilkins, 2000:2423-35.

6. Poole JB, Marcial-Rojas RA. Echinococcosis. In: Marcial-Rojas RA, ed. Pathology of Protozoal and Helminthic Diseases. Baltimore: Williams \& Willams, 1971:635-57.

7. Harris JD. Rupture of hydatid cysts of the liver into the biliary tracts. Br J Surg 1965;52:210-4.

8. Weirich WL. Hydatid disease of the liver. Am J Surg 1979;138:805-8.

9. Saidi F, Nazarian I. Surgical treatment of hydatid cysts by freezing of cyst wall and instillation of 0.5 per cent silver nitrate solution. N Engl J Med 1971;284:1346-50.

10. Rakower J, Milwidsky H. Primary mediastinal echinococcosis. Am J Med 1960;29:73-83.

11. Eroglu A, Kurkcuoglu C, Karaoglanoglu N, Tekinbas C, Kaynar H, Onbas O. Primary hydatid cysts of the mediastinum. Eur J Cardiothorac Surg 2002;22:599-601.

12. Marti-Bonmati L, Touza R, Montes H. CT diagnosis of primary

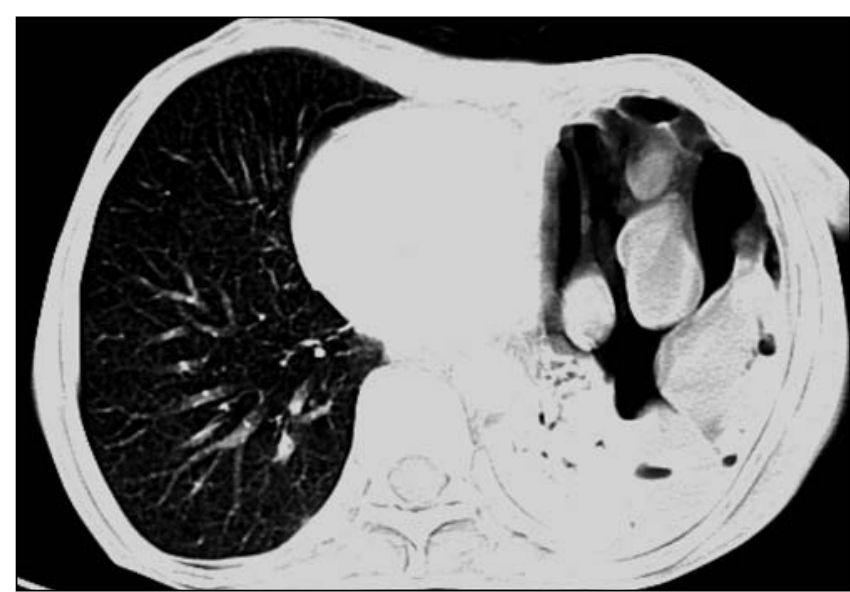

Figure 4) Contrast-enhanced computed tomography scan of the thorax showing multiple rounded opacities (daughter cysts), with partial collapse of the left lung

count are not reliable (19). Furthermore, as the correct diagnosis is rarely considered, these tests are generally not performed. The roles of computed tomography and magnetic resonance imaging have been stressed in diagnosing this disease $(20,21)$.

Peschiera (18) was able to make a correct diagnosis in only one of his 13 cases. Connellan et al (22) also failed to diagnose their case, whereas Bakir and Al-Omeri (19) reported diagnosis of tension pneumothorax in five of their cases of hydatid lung disease.

The gold standard for therapy is radical removal of germinative membrane and pericyst through appropriate thoracic incision $(2,5,10)$. When the localization of the cyst and invasion to vital structures prevents total excision, partial pericystectomy is the treatment of choice after the removal of the germinative membrane. Postoperative prophylaxis with albendazole reduces the incidence of recurrence $(23,24)$. The possibility of secondary hydatidosis due to seedlings in the pleural space is always present. The reported incidence varies from $10 \%$ to $61 \%$ (16); hence, there is a need for long-term follow-up.

mediastinal hydatid cyst rupture into the aorta: A case report. Cardiovasc Intervent Radiol 1988;11:296-9.

13. Ranganadham P, Dinakar I, Sundaram C, Ratnakar KS, Vivekananda T. Posterior mediastinal paravertebral hydatid cyst presenting as spinal compression. A case report. Clin Neurol Neurosurg 1990;92:149-51.

14. Sharma SK, Eggleston FC. Management of hydatid disease. Arch Surg 1969;99:59-63

15. Handa AK, Eggleston FC. Pneumothorax caused by hydatid cyst. Indian J Chest Dis Allied Sci 1982;24:47-9.

16. Xanthakis D, Efthimiadis M, Papadakis G, et al. Hydatid disease of the chest: Report of 91 patients surgically treated. Thorax 1972;27:517-28.

17. Saidi F. Surgery of Hydatid Disease. London: WB Saunders, 1976:268-77.

18. Peschiera CC. Hydatid disease of the lung. In: Shields TW, ed. General Thoracic Surgery. Philadelphia: Lea and Febiger, 1972:666-98.

19. Bakir F, al-Omeri MM. Echinococcal tension pneumothorax. Thorax 1969;24:547-56.

20. von Sinner W, te Strake L, Clark D, Sharif H. MR imaging in hydatid disease. AJR Am J Roentgenol 1991;157:741-5.

21. Choji K, Fujita N, Chen M, et al. Alveolar hydatid disease of the liver: Computed tomography and transabdominal ultrasound with histopathological correlation. Clin Radiol 1992;46:97-103.

22. Connellan SJ, Jowett AW, Wilson RS. Hydatid disease presenting as tension pneumothorax. Br J Dis Chest 1979;73:405-6.

23. Dogan R, Yuksel M, Cetin G, et al. Surgical treatment of hydatid cysts of the lung: Report on 1055 patients. Thorax 1989;44:192-9.

24. Karaoglanoglu N, Gorguner M, Eroglu A. Hydatid disease of rib. Ann Thorac Surg 2001;71:371-3. 


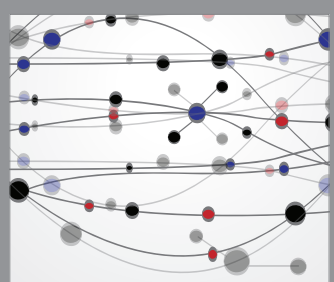

The Scientific World Journal
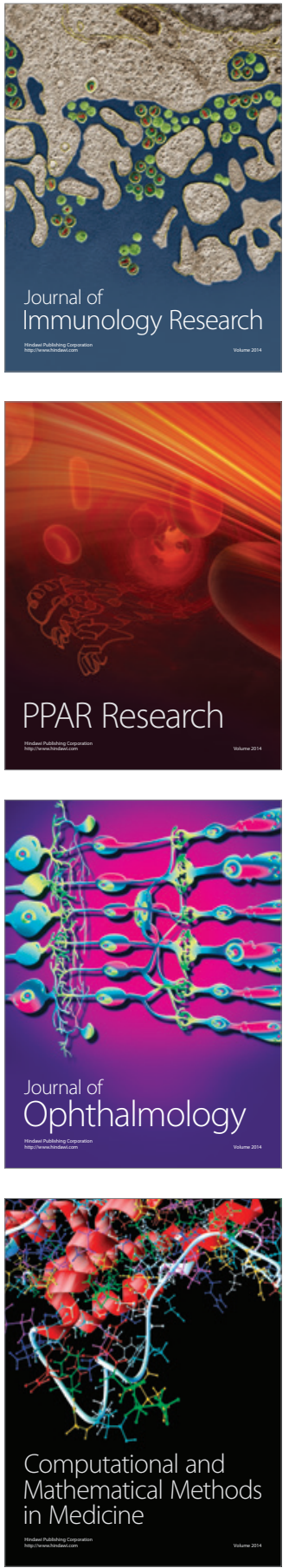

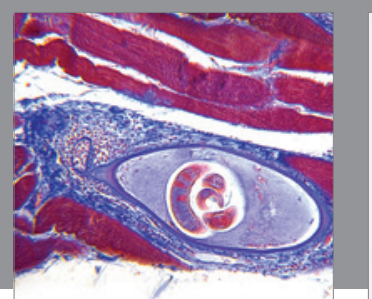

Gastroenterology Research and Practice

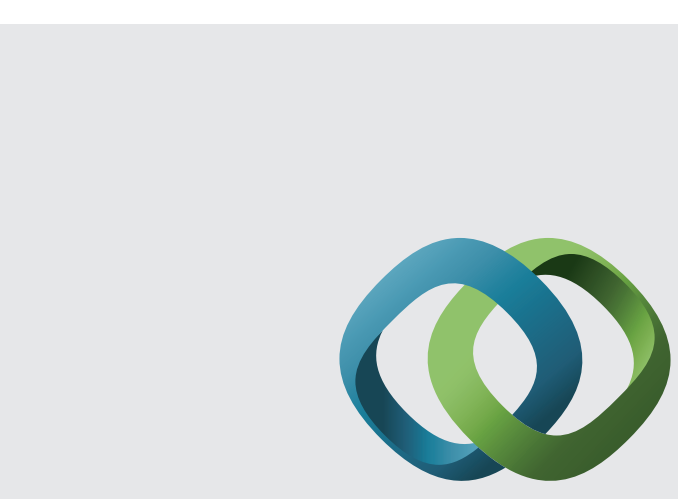

\section{Hindawi}

Submit your manuscripts at

http://www.hindawi.com
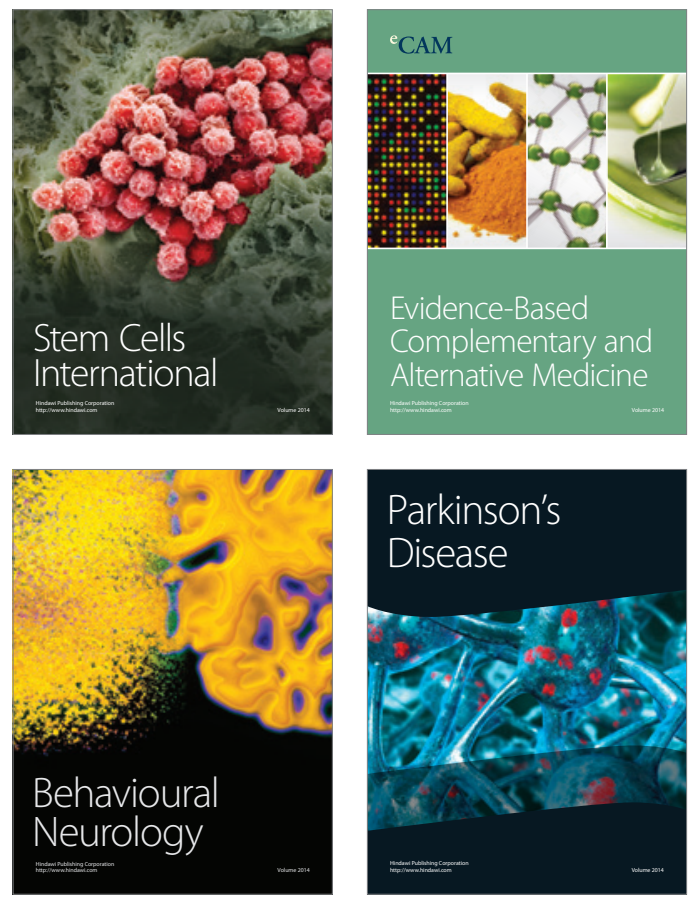
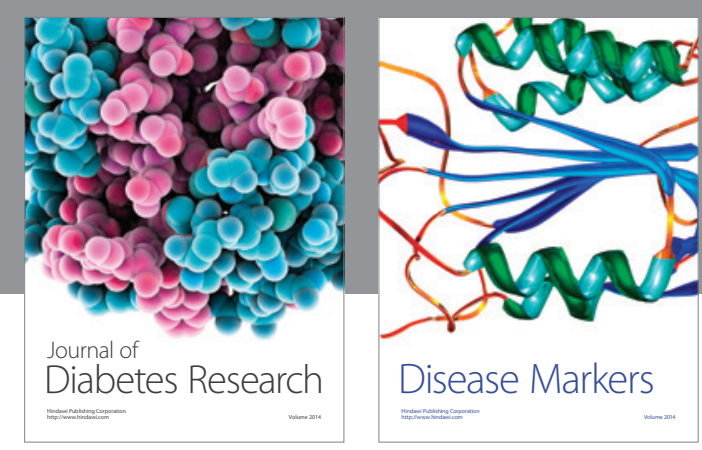

Disease Markers
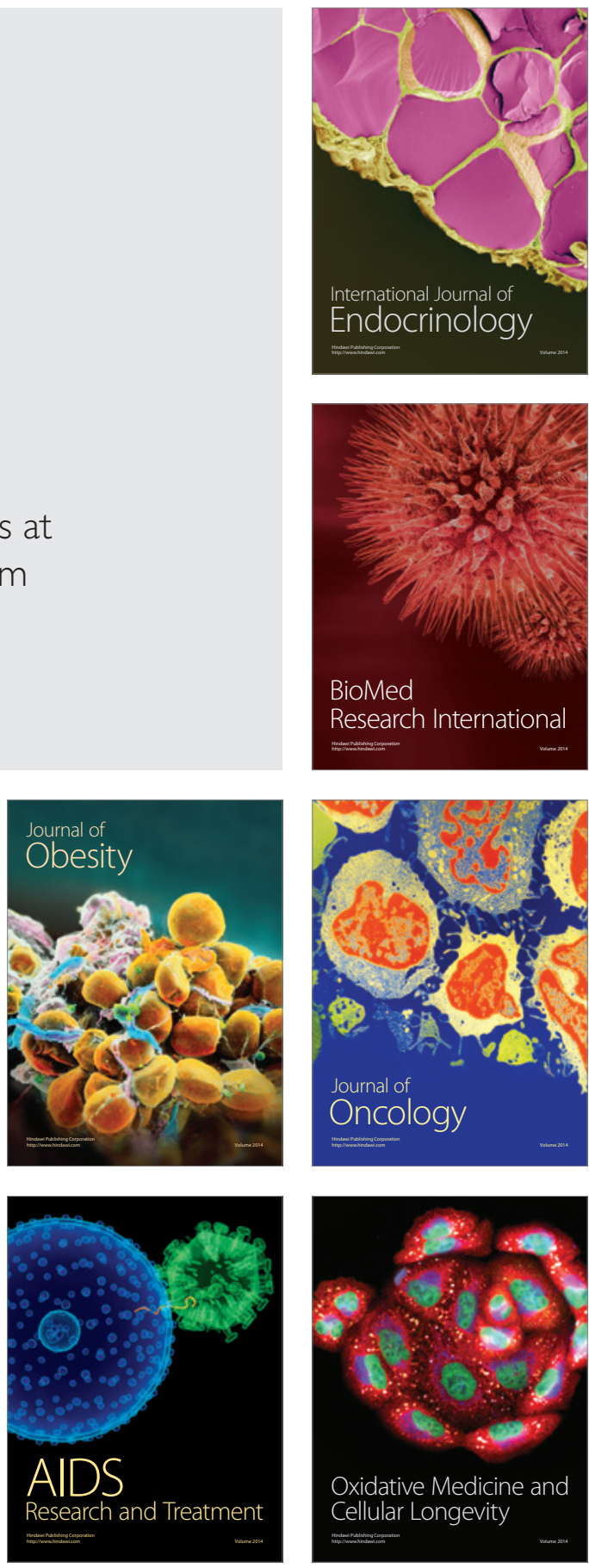